Fikrah: Jurnal Ilmu Aqidah dan Studi Keagamaan

issn 2354-6174 eissn 2476-9649

Tersedia online di: journal.iainkudus.ac.id/index.php/fikrah

Volume 8 Nomor 2 2020, (225-242)

DOI: 10.21043/fikrah.v8i1. 6711

\title{
Gerakan Indonesia Tanpa Pacaran (GITP): Propaganda and Mobilization of Youths' Social Praxis
}

\author{
Akhmad Sulaiman \\ Universitas Islam Negeri Sunan Kalijaga Yogyakarta, Indonesia \\ akhmadyusuf889@yahoo.com
}

\begin{abstract}
Abstrak
Gerakan Indonesia Tanpa Pacaran (GITP) merupakan gerakan dakwah yang lahir karena dorongan kepanikan moral. Gerakan ini khawatir pergaulan bebas di antara kaum muda semakin tidak terkontrol. Gerakan yang melancarkan misinya melalui media sosial ini ditentang banyak kalangan. Meskipun demikian, gerakan ini berkembang pesat dan memperoleh banyak pengikut. Penelitian ini bertujuan untuk mengetahui: 1) berbagai faktor yang menyebabkan GITP bisa berkembang pesat meskipun GITP ditentang banyak kalangan; 2) Teknik-teknik propaganda yang digunakan oleh GITP untuk mendapat banyak pengikut; 3) Upaya GITP dalam memobilisasi praksis sosial kaum muda. Penelitian ini menggunakan analisis wacana kritis Fairclough. Hasil dari penelitian ini adalah 1) Kesuksesan GITP tidak lepas dari totalitas propaganda; 2) GITP menggunakan tujuh teknik propaganda; 3) Mobilisasi praksis sosial dilakukan melalui tiga fungsi wacana yaitu fungsi ideasional, indentitas, dan relasional sehingga menghasilkan kesalehan personal dan komunitas militan.
\end{abstract}

Kata kunci: GITP, media sosial, mobilisasi sosial, propaganda

\begin{abstract}
Gerakan Indonesia Tanpa Pacaran (GITP), as a da'wa movement, rises because of moral panics encouragement. It is concerned that promiscuity among youths is increasingly out of control. The Movement presenting its mission through social media is opposed by many circles. Nonetheless, it develops rapidly and obtains many followers. This research is meant to answer questions: 1 ) why does GITP develop rapidly although it is opposed by many circles? 2) What propaganda techniques are used by GITP so that it receives many followers? 3) How does GITP mobilize youths' social praxis? To answer these questions, I use Fairclough's critical discourse analysis. The research concludes that the triumph of GITP is not
\end{abstract}


separated from the totality of propaganda. It uses seven propaganda techniques. Mobilization of social praxis is done through three discourse functions namely ideational, identity, and relational function of discourse till it produces personal piety and militant community.

Keywords: GITP, social media, social mobilization, propaganda

\section{Introduction}

Gerakan Indonesia Tanpa Pacaran (Indonesian Movement without Courtship), hereinafter GITP, comes as an expression of moral panics (Kailani, 2011, p. 3). Thompson (1998, p. 43) says that there is no concern about promiscuity (pergaulan bebas) in the level of age categories beyond a young age. The young age is an age in which someone is still unstable with his choice. A wrong environment can cause him to fall into promiscuity. The problems such as courtship, free sex, unwed pregnancy are the undeniable and massive phenomenon in Indonesia. GITP was established in 2015 to solve these problems (Mubarok, 2019). Nevertheless, this movement is not free from criticism and rejection. For some people, it is too narrow-minded because it offers a dichotomous option between courtship and marriage at a young age. Though choosing not to court does not mean having to get married at a young age. Another response is that choosing to court and not to court is a personal matter. So, GITP has no right to interfere in the personal matter. In Tirto, Hidayat and Khalika (2018) instead consider this movement as a business venture.

Even though it receives a lot of negative responses, in fact GITP has developed rapidly. Social media is an instrument used by this movement. In 2015 La Ode Munafar, the initiator of GITP, started propaganda through Facebook, then Instagram and Twitter. In just a few years, GITP has gained many followers. Now, GITP is having 917,135 group members and 498,644 fans page likers on facebook and 1,000,000 followers on Instagram and 2351 followers on Twitter. GITP is also having 32 communities spread across Indonesian cities. In 2018, GITP even held The Grand Declaration of Indonesia without Courtship in Bekasi that was attended by youths from Java, Sumatera, Borneo, and Sulawesi. It indicates that the religious discourse propagated by GITP has been able to mobilize youths' social praxis (Fairclough, 2010). Based on this background of the problem above, I am encouraged to explore deeply into GITP based on questions: why does GITP develop rapidly amid many negative responses and rejections? What propaganda techniques does GITP use so that it has many followers? How does GITP mobilize youths' social praxis? 
Research on da'wa and new media has indeed been done, but research focusing on $d a^{\prime} w a$ /propaganda as a discourse that mobilizes social praxis has never been done. Teitelbaum (2002) brings the issue of $d a^{\prime} w a$ and new media into a political discussion. He highlights how the government of Saudi Arabia restricts the da'wa movement of the opposition community on the internet. Gräf (2007) focuses on the activities of a scholar who have global popularity namely Yusuf al-Qaradawi in cyberspace. Similar studies are also carried out by M. Hidayat (2018), Annisa (2018), and Saifullah (2019). Nisa (2018) conducts a bolder study by highlighting da'wa activities on social media as a business. Actually, Miski (2017) has tried to explore religious discourse on social media but he has not connected the discourse with its social effect. He chose to connect it with its motive. Based on this map, my research has a number of contributions. First, it is to start a new discussion about $d a^{\prime} w a$ and new media concerning the mobilization of social praxis. Second, it is to inform effective $d a^{\prime} w a /$ propaganda techniques so that they can become a reference for other propaganda movements. Third, it is to advocate the significance of new media in religious discourse.

In this research, I place GITP propaganda as a discourse. According to Fairclough (1989, p. 43), discourse is a communicative event playing a role as a construct of the system of meaning and knowledge, social identity, and social relation. Still in his theory, discourse has three dimensions that should not be overlooked namely the dimension of text, the dimension of discursive praxis, and the dimension of social praxis. The dimension of text closely relates to linguistic aspects such as transitivity, modality, metaphor, interactional control, and ethos. The dimension of social praxis correlates with society. The dimension of discursive praxis is a connection between text and social praxis in which the text can form and be formed by social praxis (Fairclough, 1989; Jorgenson \& Phillips, 2002). Critical discourse analysis is a research logic that still requires other theories as analytical tools. Fairclough himself recognizes it. According to him, as quoted by Jorgenson and Philiphs (2002, pp. 86-87), Critical discourse analysis and analysis of other sciences can complete each other. In this research, I involve the propaganda theory as a tool for text analysis and psychoanalysis as a tool for analysis of social praxis.

Propaganda is an attempt to reproduce ideas that appear unnaturally. It means that ideas are disseminated with effort and do not develop by themselves. In the beginning, propaganda was a neutral term in the sense of not having negative connotations as often understood in the political course. 
This term was even first attached to efforts to spread religious teaching. In 1622, Vatican organized a congress entitled "Congregation for Propaganda of Faith" aimed at harmonizing the content and teaching of religion in its mission and consolidating power (Black, 2001; Cull, Culbert, \& Welch, 2003). This meaning is used in the research. Lee and Lee (1995, pp. 14-16) classify propaganda techniques into seven types namely name-calling, glittering generality, transfer, testimonial, plain folks, card stacking, bandwagon. Their definitions will be explained in the discussion of Propaganda of GITP.

Psychoanalysis highlights the human personality in three aspects. These are id, ego, and super ego. The id is human subconscious encouragement that gives rise to the mental expression of human in act of wanting to eat and have sexual relation. The super ego is a ideal expectation of society in the form of moral and religious values. While the ego is the center determinant of human personality whether it will follow the super ego or the id (Pals, 2012, hal. 8692). In this research, the religious discourse that GITP propagates to its audiences is positioned as a super ego. It requires an ideal state of Islamic socialization without courtship and other free relationships. This research highlights GITP followers' social praxis decided by their ego as a result of the dialectics between their id (sexual encouragement includes courtship) and super ego (ideal expectation/ Islamic socialization).

\section{Method}

Data collection and analysis work within the frame of three dimensions of discourse namely the dimension of text, the dimension of discursive praxis, and the dimension of social praxis. The data sources of the dimension of text are @indonesiatanpapacaran Instagram account posts. So that the data is not saturated, I limit online observing from 24 to 31 March 2019 considering that posts of the account can reach 20 times a day. In addition, its posted contents have a similarity. The production and consumption of text as parts of discursive praxis dimension require me to conduct interviews with a content creator and audiences of texts. For the former, I interview Adjih Mubarok as a founder, activist and content creator or administrator of @indonesiatanpapacaran account while the latter I interview GITP followers who are classified into three categories. They are 1) @indonesiatanpapacaran account followers only, 2) the followers who are GITP members, and 3) the followers who are members of GITP local communities. For the third category, I take samples in the GITP community of Yogyakarta. Data elaborating on followers' social praxis is 
obtained from interviews with three types of followers above, observations by attending GITP recitations and watching live streaming of GITP recitations in other cities via Instagram, and watching videos uploaded in Indonesia Tanpa Pacaran Youtube Channel. Filed data collection takes place from 18 March 2019 to 18 June 2019.

Representative samples of the account posts during 24-31 March 2019 are taken for analysis. Analysis of the text dimension not only uses linguistic theory but also propaganda theory. The second is even more dominant here because it is a research problem formulation. In the display, the analysis of text dimension and production of text as the first part of the discursive praxis dimension are united. It also occurs in the analysis of consumption of text as the second part of the discoursive dimension and the social praxis dimension . In principle, the critical discourse analysis is to find a link between discursive text and social praxis both text as an element influenced by social praxis or an element influencing it.

\section{Discourse Social Space: Portrait of Indonesian Youths' Social Praxis after the New Order}

There is a kind of agreement from Indonesian study scholars that the overthrow of Suharto regime in 1998 was a gateway to democracy, openness, and freedom (Ansor, 2016; Barker, 2015; Eddyono, 2018; Hasan, 2008; Webster, 2010; Yusuf \& Sterkens, 2015). Ideologies, movements, and identities that were previously silenced revealed their presence such as radical and militant Islamic organizations. Every person, organization, press were free to express, think, and criticize at the time. A phenomenon that had stirred up after the new order was circulating Popular Magazine with a cover image of Sophia Latjuba that was not fully dressed. This magazine was reported by the group holding strong religious and cultural values to the South Jakarta Court. The Magazine's owner and supporters argued that it is freedom in a democratic country (Barker, 2015).

At this phase Indonesia, according to Webster (2010, pp. 1-3), has been in an existential crisis. The main crisis occurs in youths that are the object of the liberalization market. The Indonesian population, especially youths, have interacted with new cultures introduced through various media. These new cultures are free sex, alcohol and drug consumption, hanging out at nightclubs, consumption of pornographic images and videos, and naughty gangs. They are then referred to as promiscuity (pergaulan bebas). Pergaulan bebas term emerges as a result of friction between local culture and modernity. Local 
culture is identified with noble moral values in society while modernity is associated with technological progress, urbanization, Western hedonism, consumerism, and individualism. Socialization considered to be out the boundaries of local moral values is called pergaulan bebas (Webster, 2010). It means that pergaulan bebas term is a bad signifier from social phenomenon considered deviating from the boundaries of local and religious values.

Actually, behavioral deviations of youths from the boundaries of local and religious values do not merely rise because of the openness and freedom of the reform era (post new order). As proof, Badan Kependudukan dan Keluarga Berencana Nasional (National Population and Family Planning Agency), hereinafter BKKBN, reports that $20-30 \%$ of youths in four cities consisting of Yogyakarta, Sukabumi, Bandung, and Bogor in the 1990s had had sex without marriage. Another survey was conducted in East Java, Central Java, and Lampung in 1998. It sampled 4106 men dan 3978 women aged 15-24 years. Its finding was that although all respondents disagree with extramarital sex, $12 \%$ of respondents heeds extramarital sex as long as the couple wants to get married (Holzner \& Oetomo, 2004).

Free sex among youths has even become a target market for a condom producer. DKT Indonesia takes this opportunity by launching the Fiesta condom brand. The condom which carries the slogan "Fruity, Fun, and Safe" was introduced in December 2002. After two years of product launches, DKT Indonesia funded a survey of youths' sexual behavior in 2004. It recorded that 242 of 474 respondents had had sex. The drawback of the survey is that data collection is only in cities and loci around schools and shopping centers so that it is not representative to describe Indonesian youths as a whole (Purdy, 2006).

The latest data from BKKBN in 2017 is more representative to describe the sexual behavior of Indonesian youths because the sample is taken from all parts of Indonesia both cities and villages. The BKKBN details that $84 \%$ of young men and $80 \%$ of young women had dated. $44 \%$ of young men and $40 \%$ of young women had started dating at the age of $15-17$ years. $75 \%$ of young men and $64 \%$ of young women claimed to have held hands. $33 \%$ of young men and $17 \%$ of young women had embraced their couples. $50 \%$ of young men and $30 \%$ of young women had kissed with the opposite sex. Finally, BKKBN finds that $8 \%$ of young men and $2 \%$ of young women had had sex before marriage (Tim SKDI 2017, 2018). BKKBN also portrayed other pergaulan bebas such as consumption of cigarettes, alcohol, and drugs. It found that $55 \%$ of young men and $1 \%$ of young women had consumed cigarettes. $15 \%$ of young men and $0.3 \%$ of young women had consumed drugs (Tim SKDI 2017, 2018). 
This situation gives rise to moral panic which in turn encouraged reflective attitudes from various circles. Since 2010, the government has required each school to embed 18 character values (Kurikulum, 2010). Traditionalist groups like Nahdlotul Ulama voice the slogan "Ayo Mondok" (Let's Study in Islamic Boarding School) to invite youths to study in Islamic boarding school. Besides aiming at providing moral education, the movement which is fully supported by the ministry of religion also aims to protect youths from religious radicalization (Njoto-Fiellrard, 2015). Elsewhere, the ikhwān youth groups promote the jargon "Hijrah" actualized through religious recitation.

\section{GITP Propaganda: Effort to Propagate Ideas}

GITP, through its Instagram account, enriches previous $d a^{\prime} w a /$ propaganda movements. From the standpoint of discourse production, @indonesiatanpapacaran account follows a da'wa genre of other accounts calling for return to Islamic teachings and moralities. They produce discourse moving youths toward a new popular culture that is compatible with Islamic dogma. However, it chose to create another discourse stream by not using the term "hijrah" as a signifier like other da'wa accounts such as @hijrahcinta, @hijrahquote, and @hijrahsantun account. @indonesiatanpapacaran account runs to make a difference and show the focus of $d a^{\prime} w a$.

GITP was conceived by La Ode Munafar on 7 September 2015 in Yogyakarta. Munafar introduced this movement through Indonesia Tanpa Pacaran Facebook account. In his journey, Munafar was then assisted by four friends who are Adjih Mubarok, Muhammad Adam, Ali Akbar, and Ibnu Sina. The Movement has a vision "become the forefront in fighting to eliminate courtship from Indonesia" (Munafar, 2017). To gain many followers and sympathizers, it uses other social media namely Twitter and Instagram. Instagram is the most potential media for propagating ideas because it is the most favored by youths. Pipper Jaffray's research concluded that in the second half of 2018, teenagers using Instagram reach $85 \%$. It outperformed Snapchat with a percentage of $84 \%$, Twitter with $47 \%$, and Facebook with $36 \%$ (Nurlitasari, 2018).

The propagating ideas through its Instagram account is done so massively. Within one day, @indonesiatanpapacaran account uploads consistently 14-20 posts. This way is also done by @hijrahcinta account having 1,000,000 followers and @hijrahsantun account having 593,000 followers. 
Mubarok, a founder and content creator of GITP, says that it is an attempt to get many followers. Aside from this, the posted contents in a day are always different. It stands on the assumption that every audience has different tendencies in receiving messages (Mubarok, 2019). These different contents will be described and analyzed based on the classification of propaganda techniques.

Every propagandist wants a renewal of the audiences' knowledge system so that it will produce social praxis that propagandist hopes. But the propagandist, content creator of @indonesiatanpapacaran account, realizes that the audiences do not always see what propagandist posts. Therefore, he often involves more than one propaganda technique in each discourse text production.

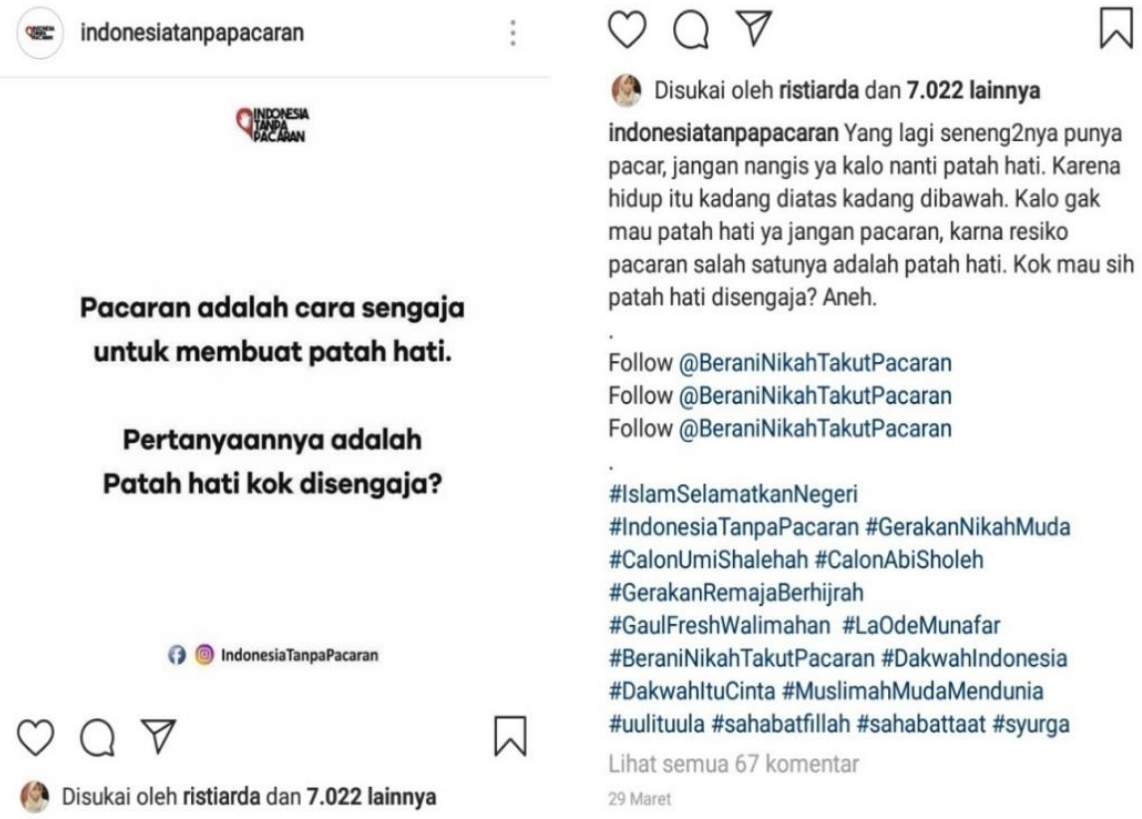

Picture 1: Name-calling and fear arousing (Source: @indonesiatanpapacaran)

The name-calling technique is used in the picture above. Bad labeling is attached to courtship by the sentence "Pacaran adalah cara sengaja untuk membuat patah hati" (Courtship is a deliberate way to make broken heart). Then, the propagandist also insinuates by saying "Patah hati kok disengaja?" (Do you deliberately break your heart?). Basically, the writing in the picture above is a propagandist's personal opinion that may be wrong. But to reinforce his idea, he uses the highest level of modality. He does not attribute the statement to a personal opinion by mentioning the phrase "menurutku" (in my 
opinion) or words introducing sentence as an opinion such as the word "mungkin" (maybe), "sepertinya" (as if) and others. In a classification of other propaganda techniques, the upload above also belongs to fear arousing technique characterized by mentioning "karena resiko pacaran salah satunya adalah patah hati" (because one of the courtship risks is broken heart).

In contrast to name-calling and fear arousing technique used as a medium of preventing violation (nahy al-munkar), glittering generality technique is used as a medium of commanding goodness (amr al-ma'rūf). Glittering generality technique is good labeling of an idea, behavior, or person. It is used so that the audiences accept propagandist's idea, behavior, or person without evidence. The propagandist tries to build an image that everyone leaving courtship is obedient to religion.

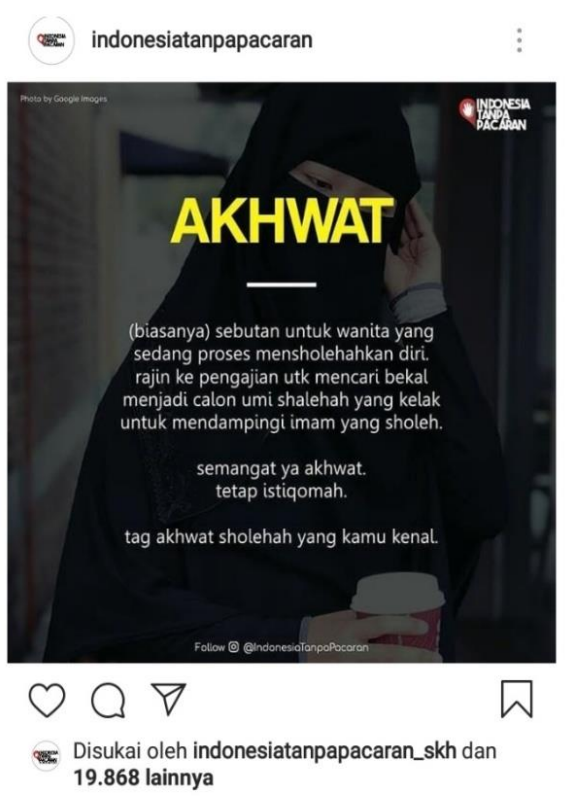

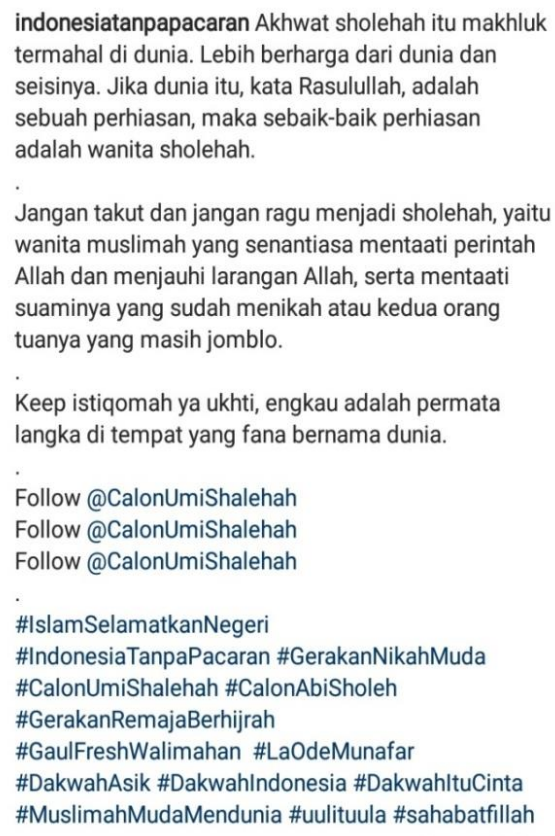

Picture 2: Glittering generality and testimonial technique (Source: @indonesiatanpapacaran)

The propagandist embeds term akhwat whose connotation is Islamic to women who are trying to edify themselves to become good prospective wives and mothers. It means that the woman who have a boyfriend, do not like to coming recitation, do not try to edify themselves are not akhwat. Actually, it is a neutral term. The term can be carried to every woman both Muslim and nonMuslim, both pious and naughty. The term in the Arabic language is even embedded as non-human in Arabic Grammar (ilm al-Nahw). The authors of the 
Arabic Grammar book use term akhwat kana, for example, as a signifier of words that have legal similarities with kana. He pins marker "makhluk termahal di dunia" (the most valuable of creatures in the world) and "permata langka di tempat yang fana bernama dunia" (the rare jewel in mortal place called the world) to strengthen influence on the audiences. The repetition of the word "jangan" (do not) in the sentence "jangan takut dan jangan ragu" (do not be afraid and do not hesitate) aims to reinforce the prohibition. Discourse communication is made closer by using greeting "ya ukhti" (o sister) and word "engkau" (you). So, the audiences seem to be invited to speak directly. To assert the narrative modality, the propagandist writes "kata Rasulullah" (according to the prophet) which is an authority holder in Islam. It is a testimonial technique. It is the involvement of a figure who is respected or hated to say that certain idea, program, behavior, or someone is good or bad.

Another technique used by the propagandist in spreading his ideology is using religious arguments taken from either the Koran or hadith binding on every believer. According to Lee and Lee theory, it is categorized as a transfer technique. Because religion is a blueprint of the social order of society (Gellner, 1981), when a propagandist feels that the state of society is not following its blueprint, he will struggle the blueprint by communicating texts of religion.
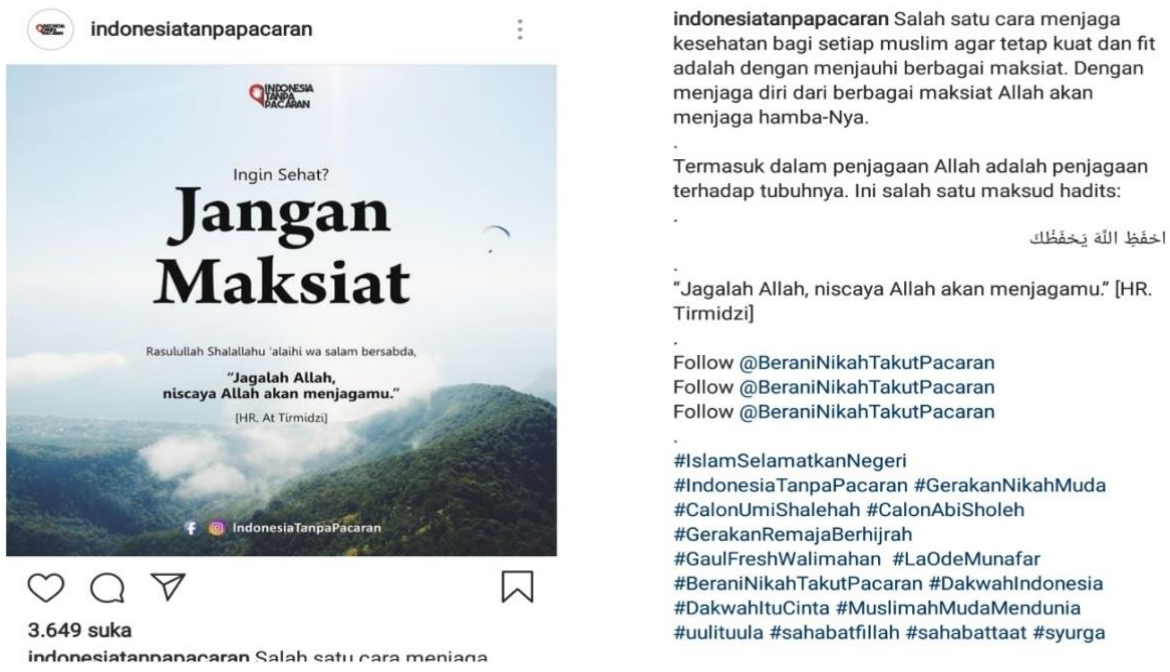

Picture 3: Testimonial technique (Source: @indonesiatanpapacaran)

By the above post, the propagandist tries to influence the audiences by saying "Ingin Sehat? Jangan Maksiat" (Want to be healthy? Do not be immoral). Based on the law of causality, this statement seems irrational because immoral acts 
are not related to human health at all. To convince the audiences, the propagandist quotes hadith "Jagalah Allah, niscaya Allah akan menjagamu" (Keep The God, surely The God will take care of you). With authoritative text, he does not require close communication.

The propagandist also uses card stacking technique to persuade the audiences in order to follow his ideology. This technique is done by making an illustration or presenting facts from reliable news sources.

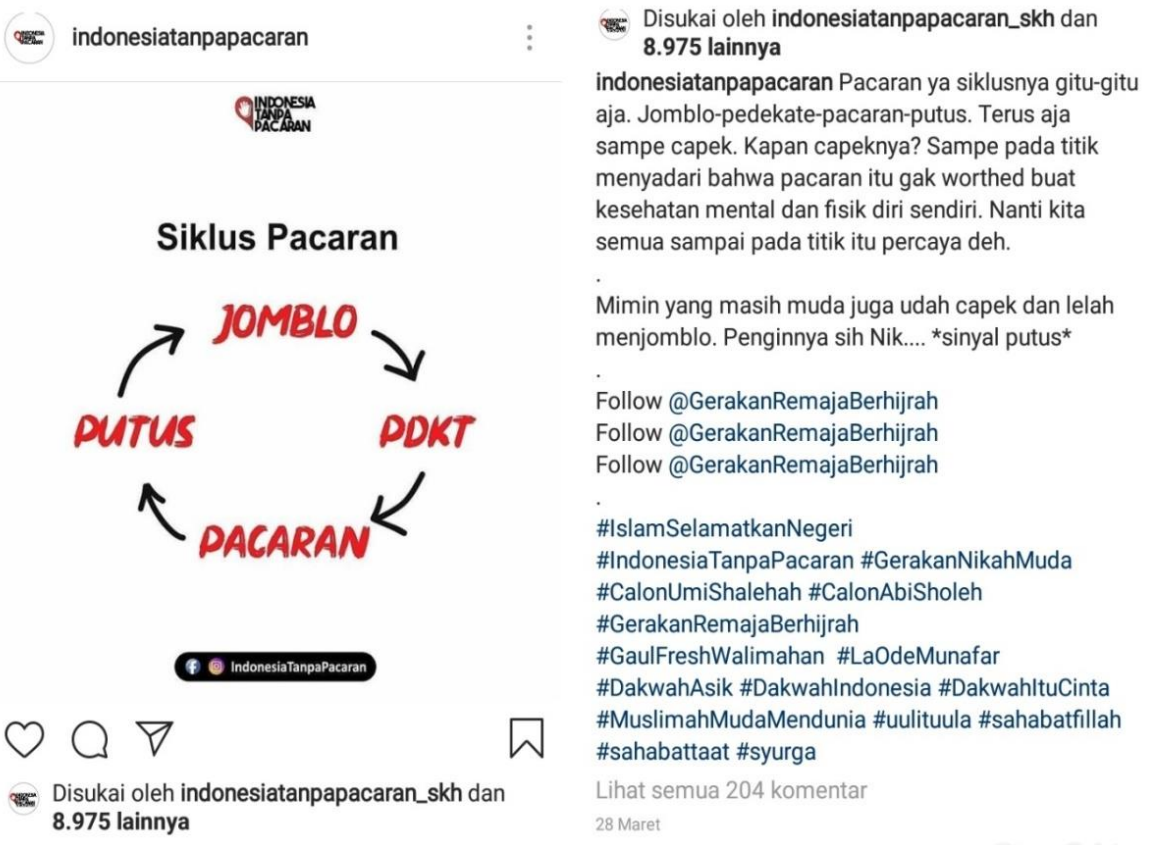

Picture 4: Card stacking, name-calling, and plain folks technique (Source: @indonesiatanpapacaran)

The propagandist presents an illustration of the courtship cycle. Although this illustration is rational, it denied another possibility. It denies the possibility of marriage after courtship. He also uses name-calling technique by saying "Pacaran itu gak worthed buat kesehatan mental dan fisik diri sendiri" (Courtship is no worth for your physical and mental health). He struggles to establish close discourse communication by using pronoun "kita" (us). Considering that the audiences are youths, he also tries to get close by saying "Mimim yang masih muda juga udah capek dan lelah menjomblo" (The administrator who is still young is also tired with loneliness). It is done so that the audiences feel that they have something in common with him so that propaganda is accepted. This technique is called plain folks. Plain folks 
technique is a technique used by propagandist to convince the audiences that the idea is good because the propagandist is one of the common people or has similarities with audiences.

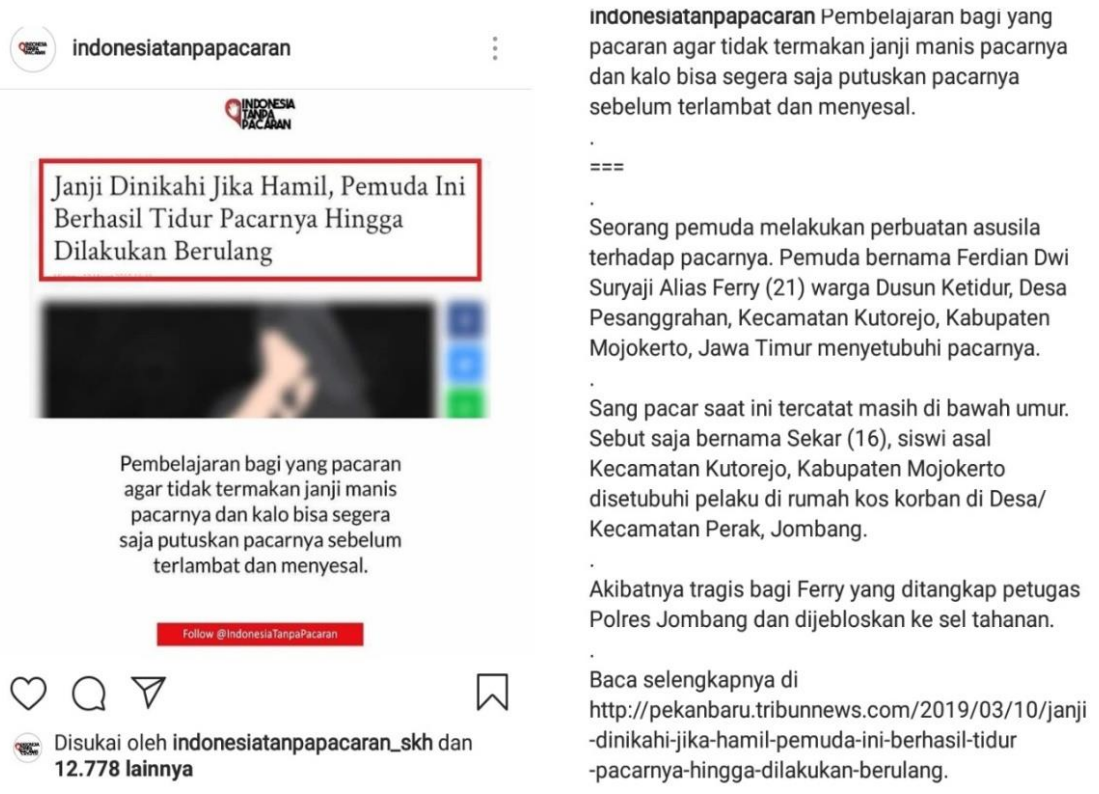

Picture 5: Card stacking technique (Source: @indonesiatanpapacaran)

The picture above is another example of a card stacking technique. The propagandist endeavors to suggest the audiences by presenting the fact about negative effects of courtship. Subsequently, he issues a persuasive statement in order that the audiences leave courtship. Its news source is shown to build their trust in the truth of the news. Informing the audiences about the negative effects of promiscuity with the rational argument is also suggested by Abudinnata in teaching sex education material (Nata, 2012).

\section{Mobilization of Youths' Social Praxis: Employing Ideational, Identity Function, and Relational Function of the Discourse}

GITP seeks to calm the moral panics through propagating ideas that is following Islamic teaching in its conviction. This movement makes serious efforts to spread new popular culture in the form of socialization without courtship. To realize the idea, each individual, in Mubarok's opinion, needs three shields namely individual shield, community shield, and state shield. The individual shield is the religious doctrine that is firmly embedded in every individual. The community shield is a group of individuals who have strong 
faith and always remind each other. The state shield is upholding sharia. Nevertheless, the third shield is not a struggle of Munafar and his followers (Mubarok, 2019). Moreover, the dissolution of Hisbu Tahrir Indonesia (HTI) is still a hot issue (Taufik, 2018). So, the formation of individual and community shield is the intention of GITP struggle.

The formation of the two shields is fought through three discourse functions namely ideational function (meaning and knowledge system), identity function (social characteristics), and relational function (Fairclough, 1992). The ideational function targets audiences' cognition while the identity function and the relational function are the consequence of cognitive understanding that is manifested in social praxis. Uploading images, videos, and captions in @indonesiatanpapacaran account is a process of internalizing the idea from the text producer (read: the propagandist) to the text consumer (read: the audiences). Text producer constructs meaning and knowledge on the audiences' cognition that Islamic socialization is interaction without dating, free sex, preserving a view of the opposite sex, and avoiding all other forms of promiscuity.

The level of knowledge function which then embodies social praxis in the form of identity and social relation is different among the audiences. Generally, the audiences who are merely Instagram follower claim that their commitment not to court, borrowing Gellner's theory (1981, pp. 1-7), often take flux and reflux (The account followers, 2019). @indonesiatanpapacaran account posts as superego create commitments or, at least, strengthen them not to court and fall into promiscuity. Religious text both the Koran and hadith (transfer technique) and adverse effects of courtship (card stacking technique) uploaded are the most influential kinds among all various posts. However, because they do not always see @indonesiatanpapacaran account posts, besides they also see most of their friends court, their id encouragement to court rises again. This category, the Instagram follower only, is reluctant to join as the GITP member because it believes that this movement has been commercialized.

Followers who are GITP members and who are members of the local communities are relatively committed not to court. Their id encouragement to court can be tempered by religious material (superego) obtained in the given period. Each GITP member gets hijrah materials twice a week in the WhatsApp group from the center organizer of GITP. While followers who are members of the local communities receive the materials from periodically religious recitation. In these two categories, a community shield is created in which they 
can remind each other to keep their commitment to not court. Generally, these two categories have a strong commitment to avoid court because their id encouragement can be absorbed by the shield (GITP members, 2019; Members of GITP Local Communities, 2019).

Social praxis of the ikhwan (brothers) and the akhwat (sisters), thus the signifiers that they use to greet each other, is reflected in social identity and relation. Like other young woman taking hijrah (transformation), the akhwat characterize themselves with a robe and a large veil (hijab). The mask (niqab) is also an identity of some akhwät. While the ikhwan tend to appear normal. They use trousers until ankles (isbāl) and do not stretch a beard. Both the ikhwan and the akhwat try to keep their distance from the opposite sex. It is a praxis that I meet in GITP Community of Yogyakarta. When they attend recitation, they are taking place in one room but the committee puts shutter up in order that they can maintain sight of each other.

Until now, GITP has been having 32 local communities in Indonesian cities. They are Yogyakarta, Sukoharjo, Jakarta, Jakarta Utara, Palu, Bekasi Town, Bekasi Regency, Palembang, Sulawesi Selatan, Samarinda, Tasik Malaya, Klaten, Subang, Pondok Gede, Wonosobo, Banten, Karanganyar, Musi Banyuasin, Pemalang, Cirebon, Pekan Baru, Indramayu, Pekalongan, East Luwu, Palopo, Brebes, Kuningan, Bengkulu, Paser, Makasar, Aceh Tamiang, and Palangkaraya. Most of these communities are solid, militant, and well established. This claim is concluded by the quantity of followers, intensity of recitation, and action on the road documented on Instagram accounts of each community. Some local communities that have not been solid, militant, and well established are GITP Community of Klaten, Pemalang, Subang, Paser, Jakarta Utara, dan Makasar.

The central organizer of GITP builds solid, militant, and well established local communities through local recitation. At the end of the recitation, he leads followers to become sympathizers of the movement with pledge (iqrar) of agreement, loyalty, and support for GITP. To make this pledge strong, he begins guidance of pledge with words "Demi Allah" (By God) to be imitated by the followers. At the time, he or speaker of the recitation usually also challenges the audiences to break their boyfriend or girlfriend at recitation place by phone. The committee will give rewards to audiences breaking her boyfriend or his girlfriend. The recitation filled by the central organizer, especially by Munafar, can be attended by thousands of participants. 
Militancy, solidity, and well establishment of every local community of GITP depend on the commitment of the local community organizer. It is because the central organizer does not interfere too much with the local communities. Because GITP is a da'wa movement, leader or coordinator of the local communities is not appointed by the central organizer on the basis of certain criteria but on a voluntary basis (Mubarok, 2019). It makes different intentions among local communities. A GITP member from Bandung who is interviewed online admitted that he cancels his plan to form a community in his hometown due to difficulty in coordinating with the central organizer.

Through the @indonesiatanpapacaran account, the central organizer offers products that read "Indonesia Tanpa Pacaran" in the form of $\mathrm{t}$-shirt, jacket, mask, key chain, hat, and book. The sale of these products is considered by some circles to be commercialization (R. Hidayat \& Khalika, 2018). However, this article is not to approve and refute this assumption because it focuses on GITP as a da'wa movement. As a da'wa movement, the sale of these products aims to show their existence and increase popularity. Because of many people wearing products that read "Indonesia Tanpa Pacaran" in public spaces, the movement is going to be more easily recognized by many people.

GITP often shows its existence by taking action on the highway like students who demonstrate. They wear clothes, accessories, and flags that read "Indonesia Tanpa Pacaran". The biggest action conducted was the event of the Great Declaration of "Indonesia Tanpa Pacaran" on April 15, 2018, in Bekasi. The event was begun by long march on the highway as an expression of moral panics. It is attended by participants from various regions both java and other islands such as Sumatera, Sulawesi, and Borneo. Showing its existence is also carried out individually or in a small group. The sympathizers take a picture in a crowded place by using an attribute labeled "Indonesia Tanpa Pacaran". This finding also completes the theory of social movement which, until now, always introduces that mass mobilization only associated with political affair (Hasan, 2012). By this finding, the writer proposes that mass mobilization can also be associated with morality affair.

GITP whose vision is to eliminate courtship from Indonesia in 2024 makes marriage at a young age a solution. In its posts, the @indonesiatanpapacaran account often introduces @gerakannikahmuda and @menjadiumisholihah account. GITP also frequently unites young women and young men for acquaintance, engagement, and marriage. The appeal of marriage at a young age is only based on a religious perspective without 
considering other perspectives such as psychology, health, and sociology so that, in my opinion, it needs to be reviewed. BKKBN requires eight family functions to achieve a healthy and happy family. They are the function of religion, love and affection, social culture, reproduction, protection, economy, education, and environmental preservation (BKKBN, 2018).

\section{Conclussion}

The triumph of propaganda to gain many followers occurs if the propaganda is executed in totality. This effort is carried out by GITP. The consistency in spreading ideas is a form of totality propaganda. The propagandist or content creator of GITP does not think enough if the propaganda content is posted once or twice a day. According to him, it must be posted a dozen times. Propaganda techniques used are very varied namely name-calling, glittering, generality, transfer, testimonial, plain folks, card stacking, and bandwagon. The propagandist even uses a combination technique frequently. Substantially, the contents of @indonesiatanpapacaran account suggest to leave courtship and recommend marriage at a young age as a solution.

The GITP propaganda carried out through three discourse functions namely ideational, identity function, and relational function at least succeed in mobilizing youths into two forms of social praxis namely personal piety and militant community. These two results are obtained from discursive propaganda through social media and religious recitation conducted by the GITP. Personal piety is manifested when superego (religious material) dominates in a person and defeats the bad influences of the promiscuity of the surrounding environment. The militancy of local communities of GITP depends on the fighting spirit of the local organizer or coordinator. It is because coordination between the central and local organizer is not well. If it continues, the vision of Indonesia without courtship in 2024 will not be realized.

\section{Recommendations}

Based on this research, writers recomend:

To researchers, studies about religious discourse in social media have to continued by comparative studies or by other theories of discourse like discursive psicology or critical social constructionist research. 
To da'wa activists, the da'wa activitities need to a totality and consistency in order to gain many audiences.

To students, the social media is a new object research having many aspects to be approached by various perspective till it is not only entertaiment media but academic media.

\section{References}

Annisa, F. (2018). Hijrah Milenial: Antara Kesalehan Dan Populism. Maarif Journal, $13(1), 38-54$.

Ansor, M. (2016). Post-Islamisme and the Remaking of Islamic Public Sphere in Postreform Indonesia. Studia Islamika, 23(3), 471-515.

Barker, T. (2015). Sex on Indonesia's Screens. In L. Bennett \& S. G. Davies (Ed.), Sex and Sexuality in Contemporary Indonesia: Sexual Politics, Diversity, and Representations (hal. 253-272). Routledge.

BKKBN. (2018). Kuatkan 8 Fungsi Keluraga Untuk Kesejahteraan Keluarga. BKKBN.

Black, J. (2001). Semantics and Ethics of Propaganda. Journal of Mass Media Ethics, $16((2 \& 3)), 121-137$.

Cull, N. J., Culbert, J., \& Welch, D. (2003). Propaganda and Mass Persuasion: A Hystorical Encyclopedia, 1500 to Present. California: Santa Barbara.

Eddyono, S. (2018). Intertwining of Educational Dualism in post-New Order Indonesia. Jurnal Ilmu Sosial dan Ilmu Politik, 22(2), 168-172.

Fairclough, N. (1989). Language and Power. New York: Longman.

Fairclough, N. (1992). Discourse and Social Change. Cambridge: Polity press.

Gellner, E. (1981). Muslim Society. Cambridge: Cambridge University Press.

GITP members. Interview with the GITP members. , (2019).

Gräf, B. (2007). Shekh Yusuf al-Qaradawi in Cyberspace. Die Welt des Islams, 47(3/4), 403-421.

Hasan, N. (2008). Laskar Jihad: Islam, Militansi, dan Pencarian Identitas di Indonesia Pasca-Orde Baru. Jakarta: LP3ES \& KITLV.

Hasan, N. (2012). Islam Politik di Dunia Kontemporer: Konsep, Genealogi, dan Teori. Yogyakarta: Suka Press.

Hidayat, M. (2018). Sedekah Online Yusuf Mansur: Otoritas dan Bahasa Agama di Media Sosial. Fikrah: Jurnal Ilmu Aqidah Dan Studi Keagamaan, 6(1), 1-24.

Hidayat, R., \& Khalika, N. N. (2018). Bisnis dan Kontroversi Gerakan Indonesia Tanpa Pacaran. Tirto.

Holzner, B. M., \& Oetomo, D. (2004). Youth, Sexuality, Sex Education Messages in Indonesia: Issues of Desire and Control. Reproductive Health Matters, 12(23), 40-49.

Jorgenson, M., \& Phillips, L. (2002). Discourse Analysis as Theory and Method. 
London: Sega Publication.

Kurikulum, B. P. dan P. P. (2010). Pengembangan Pendidikan Kebudayaan dan Karakter Bangsa. Jakarta: Kementerian Pendidikan Nasional.

Lee, A. M., \& Lee, E. B. (1995). The Iconography of Propaganda Analysis. ETC: A Review of General Semantics, 52(1), 13-17.

Members of GITP Local Communities. Interview with members of GITP local communities. , (2019).

Miski. (2017). Fenomena Meme Hadis Celana Cingkrang dalam Media Sosial. Harmoni, 16(2), 291-306.

Mubarok, A. Interview with Mubarok. , (2019).

Munafar, L. O. (2017, April). Profil Gerakan \#IndonesiaTanpaPacaran - Indonesia Tanpa Pacaran.

Nata, A. (2012). Manajemen Pendidikan: Mengatasi Kelemahan Pendidikan Islam di Indonesia (4 ed.). Jakarta: Kencana.

Nisa, E. F. (2018). Creative and Lucrative Da'wa: The Visual Culture of Instagram amongst Female Muslim Youth in Indonesia. Asia Scape: Digital Asia, 5, 68-99.

Njoto-Fiellrard, G. (2015). Ripplies from the Middle East: The Ideological Battle for the Identity of Islam Indonesia. Iseas Perspective, 2015(42), 1-10.

Nurlitasari, A. (2018, Maret). Istagram Lebih Banyak Digunakan Remaja Dibanding Snapchat. Okezone.

Pals, D. (2012). Seven Theories of Religion (I. Ridwan, Ed.). Yogyakarta: Ircisod.

Purdy, C. H. (2006). Frity, Fun, and Safe: Creating a Youth Condom Brand in Indonesia. Reproductive Health Matters, 14(28), 127-134.

Saifullah, M. (2019). Hermeneutika Alqura Virtual: Kajian atas Penafsiran Alquran Nadirsyah Hosen di Facebook, Twitter, dan Website. UIN Sunan Kalijaga, Yogyakarta.

Taufik, G. A. (2018). Proportionity Test in The 1945 Constitution: Limiting Hizbut Tahrir Freedom of Assembly. Constitutional Review, 4(1), 45-76.

Teitelbaum, J. (2002). Dueling for "Da'wa": State vs. Society on the Saudi Internet. Middle East Journal, 56(2), 222-239.

The account followers. Interview with the account followers. , (2019).

Thompson, K. (1998). Moral Panics. London \& New York: Routledge.

Tim SKDI 2017. (2018). Survei Demografi dan Kesehatan Indonesia 2017: Kesehatan Reproduksi Remaja. BKKBN, Jakarta.

Webster, T. W. (2010). Pergaulan Bebas and Genderd Youth Culture in Yogyakarta, Indonesia. University Western of Australia, Westren Australia.

Yusuf, M., \& Sterkens, C. (2015). Analysing The State's Law on Religious Education in Post-new Order Indonesia. Al-Jami'ah: Journal of Islamic Studies, 53(1), 105130. 